Science Life

\title{
HISTORY OF WHEAT BREEDING IN LATVIA
}

\author{
Vija Strazdina \\ State Stende Cereal Breeding Institute, "Dižzemes", Dižstende, Lībagu pag., Talsu nov., LV-3258, LATVIA \\ vijastrazdina@inbox.Iv
}

\begin{abstract}
A gene pool of Latvian winter and spring wheat (Triticum aestivum L.) has been created over a very long period, by collection, evaluation and selection of local genetic resources, and investigation of varieties and breeding lines from other countries in the world. It is not only a historical collection, but also serves as the foundation for research and plant breeding. National wheat germplasm is the framework for creating competitive winter and spring wheat varieties of grain with high yield, resistant to lodging and diseases, and quality acceptable for producers in the Baltic agroclimatical region. In Latvia, from 1920 to 1990, the selected wheat varieties were not stable pure lines, but mostly population varieties. After accession to UPOV (International Union for the Protection of New Varieties of Plants), the requirements for new varieties have changed, and only distinct, uniform and stable varieties, characterised by high economical value are registered in Plant Catalogues. To implement wheat breeding programmes it is necessary to improve breeding methods by plant tissue culture and production of doubled haploids (DH). During 90 years, 16 winter and 11 spring wheat varieties of bread wheat (Tr. aestivum L.) have been created at Priekuli and Stende and introduced in the market. The achievements of several generations of Latvian wheat breeders are reviewed in this paper.
\end{abstract}

Key words: winter and spring wheat, breeding history, varieties.

\section{INTRODUCTION}

In the near future, Latvian cereal breeders will acknowledge and celebrate the work accomplished in 100 years in the State Priekuḷi Plant Breeding Institute, established in 1913, and 90 years of work of the State Stende Cereal Breeding Institute, which began work in 1922. Plant breeder activities have always been closely connected with economic development and scientific progress in Latvia and in the world.

Latvia, as a transit country, has always been open for introduction of valuable and less valuable field crop seeds. Agriculturalists in Latvia at the beginning of the 20th century were certain that costly foreign seeds are only a temporary remedy to be used until competitive varieties suited to Latvian conditions will be available. Dr. agr. Jānis Lielmanis, the first director of State Stende Plant Breeding Station, in his report in 1931, stressed that plant breeding is a very important branch of agriculture, which offers to farmers varieties that are suited to the existing growing conditions, productive and resistant to diseases (Lielmanis u.c., 1931). Extensive knowledge in plant biology, genetic and experience accumulated for years is necessary for breeders. Only improvement and development of breeding methods, following the latest findings in science, can provide good results.

\section{BEGINNING OF WHEAT BREEDING IN LATVIA}

Wheat growing in Latvia was started later than elsewhere in Europe. The area under wheat in Latvia increased considerably in the 18th century when estate managers brought wheat seed from Poland and Easter Prussia. At that time the grain yield was several times lower than in Denmark and Germany, and Latvian agriculturists made a decision to start breeding activities.

Wheat breeding was started in 1922 in the Priekuḷi Breeding Station, where from 1922 till 1940 the agronomists Kārlis Vīgants, Erna Eglīte and Kārlis Lode were engaged in breeding winter and spring wheat (Anonīms, 1992).

At Stende the first trial plots of winter and spring wheat were sown in 1923. Weather conditions in the winter were thick snow and large fluctuations of temperature, which had a disastrous effect on overwintering of local and foreign wheat samples and resulted in the death of almost all wheat plants. In the following autumn, all of the wheat varieties were sown again, and thus 1924 can be considered as the year when winter wheat breeding was initiated (Anonīms, 1927.-1940). The agronomists Jurijs Garbars and Emīls Bērziņš were the first wheat breeders at Stende.

The main goal of wheat breeding was to create a new high yielding winter and spring wheat varieties, with good lodg- 
ing and fungal disease resistance, with grain quality suitable for food or feed.

At the beginning, the main objectives of wheat breeding were to:

- collect and investigate local material (landraces) from different districts of Latvia;

- test and evaluate suitability of foreign varieties to Latvian agroclimatical conditions;

- initiate breeding work (selection of elite plants from local forms and foreign varieties);

- apply hybridisation methods.

Investigation of local wheat material. Samples of winter and spring wheat were collected in different districts of Latvia and sown in observation plots. In the period from 1922 till 1939, more than 1700 local forms were listed in the wheat collection book at Stende. Before sowing, the samples were analysed for 1000 grain weight, volume weight, purity and germination (Lielmanis u.c., 1931).

The botanical composition of the winter wheat sample collection was analysed in relation to the economic value. In fields of Latvia, white awnless (albidum and lutescens varieties), brown awned and awnless (alborubrum, milturum, erythrospermum and ferrugineum varieties) wheat occurred most frequently; white awnless and white awned fluffy (anglicum Mazz. and hostianum Clem.) wheat occurred less often.

Wheat subspecies grown in Latvia have since ancient times adapted to local climatic conditions, which were extremely unfavourable in several years. All local wheat populations were characterised by low requirements to growing conditions, good winter hardiness and a short growing period. Their negative traits were: weak straw, which resulted in lodging causing considerable yield loss, easy dislodge of grain; lowest test weight and low 1000 grain weight (Garbars, 1939).

The yield of local wheat populations was lower in Kurzeme and Zemgale regions, compared to foreign varieties, but good winter hardiness, which was observed in Vidzeme region, was superior to imported varieties. The growing period of local wheat populations was 6-8 days shorter than that of foreign varieties. Analysing the collected winter wheat material, Jurijs Garbars came to the conclusion that somewhat higher yields, higher stiffness of straw and greater test weight of grain would make them superior under the unfavourable weather conditions of Latvia, but due to these negative traits, production was not cost-effective, even in low-intensive farms.

The botanical composition of local spring wheat samples was somewhat more uniform. White awned (graecum Körn), white awnless (albidum Al., lutescens Al.) and red awned forms prevailed, wheat with red awned occurred sel- dom. Awned wheat had the shortest vegetation period, but grain dislodge in the field was a negative trait.

Evaluation of foreign winter wheat varieties. Winter wheat production in Latvia began by cultivation of 'Sandomiras' wheat introduced from Poland. This material had brown, awless ears, long stems, low lodging resistance, but had good winter hardiness and baking quality. Later, 'Kuverta' winter wheat was introduced from Eastern Prussia. 'Kuverta' had higher lodging resistance, white awnless ears and relatively good winter hardiness, but poor baking quality (Anonīms, 1992).

From the beginning of 1923 up until 1938, winter wheat varieties from Sweden, Germany, Norway, Finland, Estonia, Lithuania, Poland, Denmark, France and Russia were evaluated at the State Stende Plant Breeding Station for yield, winter hardiness, growing period, and resistance to unfavourable weather conditions (sprouting), lodging, disease resistance, and grain quality traits. More than 500 samples of varieties from all European countries and even from Africa, Australia, and USA were sown in small trial plots (2-5 $\mathrm{m}^{2}$ and $10 \mathrm{~m}^{2}$ in size in 4-6 replications) and evaluated. "Sandomira" wheat was used as a standard. A great number of new varieties were included in variety trials each year.

Based on test results obtained from ten years of investigation, the varieties were divided into two groups: winter hardy and susceptible to winter conditions.

According to J. Garbar's opinion, the presence of hairs and awns was a negative trait in wheat. He has also stressed that a very small number of awned wheat varieties are found in Western Europe. All of the awned varieties tested showed lower productivity, but did not require large amounts of nutrients and were more resilient in unfavourable climate conditions.

Spring wheat material introduced from America was susceptible to diseases - plants were infected with brown rust, and none of the varieties surpassed the standard wheat 'Janecka' in yield. The quality of grain was also an important feature. After a 15-year long investigation period, several spring wheat varieties were recognised as suited to the Latvian climate: 'Rubin', 'Kitcener', 'Janecka' ('Janetzki') and 'Diamant' (Garbars, 1939).

Selection of elite plants. Along with comparing local wheat and introduced breeding material, researchers began selection of elite plants, paying the greatest attention to yield potential, resistance to fungal diseases, lodging, growing period and grain quality. Elite plants were selected mainly from populations that had been grown in Latvian farms for 10-20 years. Elite plants were taken also from foreign varieties.

In the first years, elite plants were evaluated visually, multiplied and evaluated repeatedly. In the laboratory, grain quality, plant height, and proportion of ear, grain and straw weight of the total weight of the whole plant were deter- 
mined. Winter wheat pure breeding lines were compared to standard 'Sandomira', and spring wheat with 'Janecka'.

Trial results showed that local populations of spring and winter wheat were less productive (Tables 1 and 2) and less resistant to lodging, but had a shorter growing period.

Wheat hybridisation. The first crossing combinations were started at the Stende Plant Breeding Station in 1924 for winter wheat and in 1925 for spring wheat, with the aim to obtain higher yielding varieties with a short vegetation period, and to improve grain quality. In crosses, foreign and local

Table 1

VARIETY TESTING RESULTS OF SANDOMIRA WHEAT AND LOCAL WHEAT POPULATIONS, 1927-1928, AT STENDE AND PRIEKULII PLANT BREEDING STATIONS ${ }^{1}$

\begin{tabular}{|c|c|c|c|c|}
\hline \multirow[t]{2}{*}{ Indices } & \multicolumn{2}{|c|}{$\begin{array}{c}\text { Stende Plant Breeding } \\
\text { Station }\end{array}$} & \multicolumn{2}{|c|}{$\begin{array}{c}\text { Priekuḷi Plant Breeding } \\
\text { Station }\end{array}$} \\
\hline & 'Sandomira' & $\begin{array}{l}\text { Local } \\
\text { variety }\end{array}$ & 'Sandomira' & $\begin{array}{l}\text { Local } \\
\text { variety }\end{array}$ \\
\hline Grain yield, $\mathrm{q} \mathrm{ha}^{-1}$ & 34.8 & 32.3 & 7.30 & 7.95 \\
\hline 1000 grain weight, g & 37.8 & 29.8 & 29.0 & 25.64 \\
\hline Volume weight, $\mathrm{g} \mathrm{L}^{-1}$ & 663 & 663 & 686 & 665 \\
\hline Growing period, days & 367 & 361 & 368 & 368 \\
\hline
\end{tabular}

${ }^{1}$ Lielmanis, 1931

Table 2

CHARACTERISTICS OF SPRING WHEAT VARIETIES AND LOCAL POPULATIONS IN STENDE, MEAN 1924-1928 ${ }^{1}$

\begin{tabular}{|c|c|c|c|c|}
\hline \multirow[b]{2}{*}{ Indices } & \multicolumn{4}{|c|}{ Varieties } \\
\hline & 'Janecka' & $\begin{array}{l}\text { 'Ekstra } \\
\text { Kolben' }\end{array}$ & 'Santzbeis' & $\begin{array}{c}\text { Local } \\
\text { population }\end{array}$ \\
\hline Grain yield, $\mathrm{q}$ ha $^{-1}$ & 19.32 & 19.08 & 17.50 & 15.63 \\
\hline 1000 grain weight, $\mathrm{g}$ & 33.01 & 29.80 & 31.88 & 29.44 \\
\hline Volume weight, $\mathrm{g} \mathrm{L}^{-1}$ & 733.4 & 766.0 & 730.8 & 730.0 \\
\hline Growing period, days & 111 & 115 & 114 & 107 \\
\hline
\end{tabular}

$\overline{{ }^{1} \text { Lielmanis, } 1931}$ seed material was used. With the aim to shorten the vegetation period of spring wheat, it was crossed with winter wheat. Hybridisation was also conducted with the aim to investigate a range of theoretical questions, i.e., to investigate wheat inheritance.

\section{WHEAT BREEDING FROM 1922 TO 1940}

Winter wheat breading. Wheat breeder J. Garbars started his career at the Stende Plant Breeding Station by investigating Swedish Swalöf wheat 'Söl'. This wheat had good resistance to lodging, but weak winter hardiness. Later, by selecting elite plants from 'Sandomira' wheat, he developed the winter wheat varieties: 'Viestura I', 'Viestura II', and 'Zemgales'. The variety 'Priekulu' was the third most widely sown variety in Latvia in the 1930s, and was bred at the Priekuli Plant Breeding Station. This wheat variety was suited to growing conditions in Vidzeme (Table 3). In long-term trials with winter wheat, yield fluctuations associated with winter hardiness were determined. Local wheat varieties showed the least fluctuations - coefficient of variation $19.1 \%$, compared to $25.8 \%$ for 'Priekul,u', $28.8 \%$ for 'Viestura' and $70.6 \%$ for 'Zemgales' wheat.

Spring wheat breeding. In Latvia the first new developed spring wheat varieties were 'Imanta' and 'Priekul,u' (Table 4). The variety 'Imanta', developed at the State Stende Plant Breeding Station, was suited for growing in fertile soils both in Kurzeme and Vidzeme. A negative trait was susceptibility to loose smut, and for this reason the variety was not widely introduced into the market. Spring wheat 'Priekulu', developed at the Priekul,i Plant Breeding Station, had weak lodging resistance. Breeding of spring wheat at Stende was interrupted in 1937, and was continued only at the Priekuli Plant Breeding Station.

\section{WHEAT BREEDING FROM 1941 TO 1990}

General characterisation of breeding situation in the period. During the Second World War, breeding of wheat was

WINTER WHEAT VARIETIES DEVELOPED IN LATVIA FROM 1922 TO 1940

\begin{tabular}{|c|c|c|c|c|}
\hline Variety & Origin & Originators & Year & Characterization \\
\hline 'Viestura I' & Selection from 'Sandomira' & J. Garbars & 1930 & $\begin{array}{l}\text { Brown, awnless ear, medium-high resistance to lodging, good winter hardi- } \\
\text { ness, intermediate growing period and yield. }\end{array}$ \\
\hline 'Viestura II' & Selection from 'Sandomira' & J. Garbars, E. Bērzin̄š & 1937 & \\
\hline 'Zemgales' & Selection from local wheat & J. Garbars & 1930 & $\begin{array}{l}\text { White awnless ear, high grain weight, and was resistant to lodging. Grain } \\
\text { yield was } 45 \mathrm{q} \mathrm{ha}^{-1} \text {, a negative trait - poor winter hardiness. }\end{array}$ \\
\hline 'Priekulu' & Selection from local wheat & K. Vīgants, K. Lode & 1930 & Good winter hardiness and medium-high resistance to lodging \\
\hline
\end{tabular}

SPRING WHEAT VARIETIES DEVELOPED IN LATVIA FROM 1922 TO 1940

\begin{tabular}{c|c|c|c|c}
\hline Variety & Origin & Originators & Year & Characterization \\
\hline 'Imanta' & Selection from local wheat & J. Garbars & 1933 & $\begin{array}{l}\text { Red awnless ears and red grain. Straw was medium length, resistant to lodging. } \\
\text { Over a 10-year average out yielded 'Janecka' by 18\% and wheat 'Rubin' by 10.9\%. }\end{array}$ \\
'Priekul̦' & Selection from local wheat & K. Vīgants, K. Lode & 1930 & Good productivity
\end{tabular}


practically stopped. A number of breeding lines that were developed in Stende and Priekul,i, were removed to Lielplatone and Mežotne and from Latvia to other countries Russia and Germany.

The period from 1945 to 1954 was a time of great change both in the history of our country and in cereal breeding as well. At this time, Priekuḷi and Stende Plant Breeding and Experimental Stations were under financial and administrative control of the USSR Ministry of Agriculture. Latvians and agricultural specialists from the Soviet Union with special appointments were included in the staff. In 1971, the USSR Ministry of Agriculture made a decision to establish 48 territorial complex and specialised breeding centres. Following this decision, Latvia, Lithuania and Estonia were included in the so-called "Western Breeding Centre" coordinated by the Byelorussia Agricultural Institute. The main task of the Western Breeding Centre was to organize conferences, meetings and reports of breeders, and also training courses for the young scientists.

For many years the N.I. Vavilov Institute of Plant Industry (VIR) was the only institution that increased collection of wheat varieties in Latvia. During the Soviet time, Latvian researchers were not allowed to make study trips to European countries and America and to receive breeding material straight from abroad. On the other hand, contacts were established with plant breeders in Russia and other republics of the Soviet Union, resulting in breeding material exchange and inter-station variety testing.

Winter wheat breading. The goal of breeding was to develop and introduce into production new varieties, highlyproductive, resistant to lodging and diseases, with good baking quality, suited to conditions of Latvia. In wheat breeding together with classical methods - inter variety hybridisation and individual and family selection — the new directions were used. One of them was breeding of "branched" wheat (1946-1955). The initial material was Triticum polonicum and Triticum turgidum, and the local branched wheat from Kahetia Georgia). Under Latvian conditions this wheat formed very great branched ears, but was late-maturing, with small grains and was susceptible to Fusarium spp. and powdery mildew. After several years, the investigations in this direction were stopped as unsuccessful.

The other method in wheat breeding was wheat transformation, which started in Latvia in 1948. Trials were conducted at Stende, Priekuli and the Latvian Academy of Agriculture. The wheat transformation was achieved mainly through changes of sowing time, i.e. spring wheat were sown in autumn at different sowing times, trying to change the nature of spring crop and to obtain winter wheat plants.

Professor Antonijs Valainis studied the possibilities to influence the "evolution process" by selecting the breeding material and lines with valuable economy traits and was engaged in wheat transformation until 1987. Using this method Prof. Valainis together with researchers from the
Ukraine developed the spring wheat variety 'Mironovskaya yarovaya', which was widely grown in Russia and Ukraine from 1960 to 1970 .

At Stende, from 1949 until the late 1950s, the vegetative hybridization-grafting wheat germs on the endosperm of other plant species (Triticum timopheevii (Zhuk) Zhuk, Triticum dicoccum (Shrank) Schucbl.), branch wheat and also rye, was applied with the aim to speed up the process of breeding.

Treating wheat grain with radiation was a new method which started in Priekuli in 1959. Varieties and selection lines had been exposed to radioactive Co gamma rays in five doses. Similar trials were also conducted at Stende. However, the trials which lasted for many years, did not bring positive results.

During 1970-1990, one of the main goals in winter wheat breeding programmes at the State Stende Plant Breeding Station was to select winter hardy, resistant varieties to fungal disease and pests. Winter wheat varieties and breeding lines were tested using Tilletia tritici (Bjerk), Puccinia tritici (Eriks\&Henn) (race 77, 76) and snow mould Fussarium nivale (Fr.) (Ces). Field and laboratory tests were used for testing winter wheat material to winter hardiness. Resistance to Oscinella frit (Linn) was determined using an early sowing date (the $3^{\text {rd }}$ decade of July or the $1^{\text {st }}$ decade of August). Resistance of winter wheat to powdery mildew, brown rust), yellow rust and leaf spots was assessed every year in field trials. From 1985 to 1990, winter wheat lodging resistance and morphological traits of varieties were studied using laboratory methods (Страздиня, 1987).

In the period from 1982 until 1987, more than 200 varieties of winter wheat from Russia and other countries were evaluated for economic value, disease resistance and morphological traits. Grain samples produced in Latvia were analysed for amino acids (mainly lysine) and a catalogue of varieties was established based on trial results (Чмелёва и др., 1989).

In 1945-1990, the winter wheat breeding programme resulted in seven new varieties (Table 5).

Spring wheat breeding. Spring wheat breeding was restarted in 1946, when collections from Mežotne were returned to Stende and Priekuli. Variety collections were supplemented with new varieties obtained from the N.I. Vavilov Institute of Plant Industry (VIR, Russia).

In 1945-1990, the spring wheat breeding programme resulted in the development of five new varieties, which mainly were selections from local varieties. These varieties produced grain yields of 2.5-3.5 $\mathrm{t} \mathrm{ha}^{-1}$ (Table 6).

Varieties from Russia, the Ukraine, Estonia and Sweden, were more competitive, with more stable grain yield level, and were rapidly introduced into production. In variety trials at Stende, from 1942 until 1946, good results were ob- 
WINTER WHEAT VARIETIES DEVELOPED IN LATVIA FROM 1945 TO 1990

\begin{tabular}{|c|c|c|c|c|}
\hline Variety & Origin & Originators & Year & Characterization \\
\hline ‘Kursas’ & 'Söl'/local wheat & $\begin{array}{l}\text { E. Bērziňš, } \\
\text { J. Garbars }\end{array}$ & 1940 & $\begin{array}{l}\text { Red awnless ears, long straw, good lodging resistance, intermediate winter } \\
\text { hardiness. }\end{array}$ \\
\hline 'Milturum 5' & $\begin{array}{l}\text { Selection from Stendes } \\
\text { L-11613 }\end{array}$ & $\begin{array}{l}\text { J. Garbars } \\
\text { (A. Sietinsons) }\end{array}$ & 1949 & $\begin{array}{l}\text { Red awnless ears, good lodging resistance, good winter hardiness, medium } \\
\text { grain quality }\end{array}$ \\
\hline 'Priekul̦u 118' & Selection from breeding material & J. Lindermanis & 1950 & - \\
\hline 'Priekuḷu 481’' & Selection from breeding material & J. Lindermanis & 1953 & $\begin{array}{l}\text { Good winter hardiness and productivity, and grain quality, medium resis- } \\
\text { tance to lodging. }\end{array}$ \\
\hline 'Kurzeme' & 'Jarl'/'Paix’ & $\begin{array}{l}\text { R. Kude, } \\
\text { E. Bērziňš } \\
\text { (J. Garbars) }\end{array}$ & 1956 & $\begin{array}{l}\text { White awnless ears, straw length } 100-120 \mathrm{~cm} \text {, good lodging resistance, good } \\
\text { grain quality }\end{array}$ \\
\hline 'Raive' & 'Kursa'/'Banco’ //‘Kursa’ & $\begin{array}{l}\text { R. Kude } \\
\text { V. Strazdiņa } \\
\text { E. Metuzāls }\end{array}$ & 1980 & $\begin{array}{l}\text { Good winter hardiness, productivity, and lodging resistance. Negative trait } \\
\text { — long period of vegetation. }\end{array}$ \\
\hline 'Stende' & $\begin{array}{l}\text { 'Mironovskaya'/ } \\
\text { 'Ilyicovka' }\end{array}$ & $\begin{array}{l}\text { R. Kude } \\
\text { V. Strazdina }\end{array}$ & 1981 & $\begin{array}{l}\text { Good winter hardiness, productivity, grain quality, and medium resistance to } \\
\text { lodging. }\end{array}$ \\
\hline
\end{tabular}

Table 6

SPRING WHEAT VARIETIES DEVELOPED IN LATVIA FROM 1945 TO 1990

\begin{tabular}{|c|c|c|c|c|}
\hline Variety & Origin & Originators & Year & Characterization \\
\hline ‘Priekuḷu’' & Selection from local wheat & K. Lode & 1950 & Middle early, good productivity and grain quality. \\
\hline 'Stendes 5’' & L-1143/‘Imanta’ & $\begin{array}{l}\text { K. Zagika, } \\
\text { J. Garbars, } \\
\text { E. Krēsliňš }\end{array}$ & 1952 & - \\
\hline 'Stendes’ & Selection from 'Aurora' & E. Krēsliņš & 1958 & Good grain quality and productivity, middle early. \\
\hline 'Priekulu 436' & 'Filgia'/‘Tuluna 70' & E. Bērziņš, E.Sniedze & 1964 & Average yield in 5 years was $26.2 \mathrm{q} \mathrm{ha}^{-1}$ \\
\hline ‘Liva’’ & $\begin{array}{l}\text { Selection from 'Aurora' and } \\
\text { branch wheat population }\end{array}$ & $\begin{array}{l}\text { E. Krēslin̄̌š, R. Kude, } \\
\text { M. Sovere, M. Gaike }\end{array}$ & 1971 & Middle early, good grain quality and productivity \\
\hline
\end{tabular}

tained with the spring wheat variety 'Diamant', which was developed in Sweden and had been grown in Latvia since 1933. This variety was medium-early ripening, and had high-yield and lodging resistance. From 1950 till 1967, it was the standard variety used in testing. The spring wheat 'Moskovka', which was introduced from Russia, was grown in Latvia from 1952 till 1960, and the spring wheat variety 'Pikker' from Estonia, which was a population of two varieties, from 1955 till 1970. The spring wheat 'Leningradka' (Russia) was a leading variety in Latvia from 1975 till 1990.

The USSR policy and opinion, that the wheat produced in Latvia was only suited to food, hindered the development of wheat breeding. At Stende, in 1964, breeding of spring wheat was stopped and all developed material was transferred to the Priekuli Breeding Station. However, in 1971, breeding of spring wheat in Priekuli was discontinued as well.

\section{WHEAT BREEDING FROM 1991 TO 2011}

General characterisation of the breeding situation in the period. The aim of current wheat breeding, employing classical and new biotechnology methods, are to create and introduce into production winter and spring wheat varieties adapted for conventional and organic management, with grain quality corresponding to food industry requirements, and to evaluate and maintain Latvian wheat genetic resources.

Maintenance and evaluation of the wheat genetic resources of national wheat varieties and breeding lines, selected during many years, was one of the main objectives of geneticists and breeders after the independence of Latvia. Inventory of working collections, preservation and multiplication of accessions of Latvian origin, were first initiated by the Latvian Society of Geneticists and Breeders in 1993. Later, in 1995, the GR activities were supported by the Nordic Council of Ministers in collaboration with the Nordic Gene Bank (Rashal and Weibull, 1997; Rashal, 2001; Rashal, 2002).

Most of the winter and spring wheat working collections, breeding lines and varieties are maintained at the State Stende Cereal Breeding Institute. Not all varieties bred in Latvia, especially those selected before the Second World War, exist in those collections. Only a few winter and spring wheat varieties selected from landraces in the 1920s were recognised. Several old wheat accessions were repatriated from foreign gene banks, mainly from the N. Vavilov All-Russian Plant Industry Institute (VIR) in St. Petersburg.

Since 2005, the characterisation, evaluation and molecular passportisation of plant genetic resources were included in 
the national programme. Descriptor lists harmonised with ECPGR and UPOV lists were developed for wheat accessions. The data are available for potential users worldwide.

After independence from the Soviet Union in 1991, Latvian plant breeders were able to benefit from world experience, extend their knowledge of plant breeding and seed production, genetics, plant physiology and molecular biology. Breeders could participate in professional courses organised in Sweden, USA, UK and Canada. Scientists were supported by CIMMYT (International Maize and Wheat Improvement Centre), ICARDA (International Centre for Agricultural Research in the Dry Areas) and Oregon State University to participate in International Conferences on wheat breeding and genetics in Turkey, Hungary and China (Strazdina, 1996).

Wheat breeders from Latvia were involved in International programmes (International Winter Wheat Improvement Programme) for conducting field trials and evaluating material obtained from CIMMYT, ICARDA and Oregon State University (USA). Between 1995 and 1999, more than 900 breeding lines of winter and spring wheat, developed in Oregon State University, were tested under Latvian conditions. The most promising lines were selected and used to develop new breeding lines and varieties of wheat. Annual collections of wheat were increased with recently developed and high-productive varieties received from Europe, USA, Canada, Russia, Belarus and other locations (Strazdina u.c., 1995; Strazdina et al., 2002).

Variety DUS test and UPOV requirements became important for breeders when Latvia joined the European Union. Researchers began to collect standard varieties and select homogeneous lines more precisely (Strazdina and Briedis, 2004).

In the early 1990s, the grain technological laboratory in the State Stende Plant Breeding Station was renovated and investigation on wheat grain quality was reinitiated. Investigation of wheat grain quality also was conducted in Odessa (Ukraine) at the Institute of Plant Breeding and Genetics. In 1994-1996, in Latvia, seminars on wheat breeding were organised under the leadership of Professor W.E. Kronstad from Oregon State University (Roze and Strazdina, 1993; Strazdina, 1999).

From 1987 to 2003, Dr. biol. Ina Belicka delivered lectures in plant breeding at the Department of Crop Production of the Latvian University of Agriculture, and also performed practical wheat breeding work in the Study and Research farm „Peterlauki”. Students took active part in this work, and on the basis of experiments, Bachelor's, Master's and Doctoral theses were prepared.

In 2000, the new methods of biotechnology (doubled haploids, DH) were introduced in wheat breeding programmes with the aim to speed up the breeding process. Scientists from the Institute of Biology of the University of Latvia (Laboratory of Plant Genetics) using anther culture pro- duced spring and winter wheat DH from Latvian wheat hybrids. The obtained DH lines were sown in field conditions at the State Stende Cereal Breeding Institute for field evaluation. Perspective material was used in further breeding, and the best lines were tested in VCU and DUS for new variety registration (Grauda et al., 2005; Grauda et al., 2009; 2010).

Winter wheat breading. During 20 years (1990-2010), at the State Stende CBI, 25654 winter wheat crossing combinations were made and 125456 fertile seeds were obtained. The average fertility was $35.4 \%$. At the beginning of 2000 , new created winter wheat varieties included 'Elva', 'Hugo', 'Krista', 'Sakta', and 'Banga S' (Table 7). All of the varieties had high yield, good winter hardiness, and intermediate resistance to fungal diseases and lodging. Winter wheat 'Krista' and 'Sakta' were registered in the Latvian Plant Variety List in 1994, and variety 'Banga $S$ ' in 2002. The varieties were mid-intensive, had good winter hardiness, but low lodging resistance (Strazdina, 1999; Strazdiņa et al., 1999; Strazdina, 2008) (Tables 8 and 9).

Winter wheat variety 'Moda' ('Otto') was developed in the Latvian University of Agriculture. For wheat breeding purposes, parent material was received from the Stende Plant Breeding station. This wheat variety has high yielding, lateripening, it is winter hardy and responds to nitrogen fertilisation, and has good bread baking quality. The winter wheat "Moda" was added to the Latvian Plant Variety List in 2001 (Belicka, 2002).

The winter wheat variety 'Banga S' had high yield, intermediate winter hardiness, and grain quality mostly acceptable for feed and bioethanol production (Strazdina un Krotovs, 1996).

The winter wheat 'Fredis' has good winter hardiness, earliness, good lodging resistance, and grain quality suitable for bread baking. The variety was registered in the Latvian Plant Variety Catalogue in 2007 and in Estonia in 2011. VCU and DUS testing was carried out for winter wheat varieties 'Talsis' (L-96-58) and 'Edvins' ('St.A-1').

The utilisation of wheat grain is large-scale, and not only for food or feed, but also for starch and bioethanol production.

Spring wheat breading. Since 1990, breeding of spring wheat was reinitiated at the State Stende Plant Breeding Station. In the late 1980s and in the beginning of the 1990s there was an insignificant area cultivated with spring wheat and only a few varieties were available to farmers. At first breeders renewed the spring wheat collection, mostly with varieties from Russia, Poland and Germany. Material from Oregon (USA), Sweden and other countries were later used in hybridisation (Strazdina and Bleidere, 2004; Strazdina et al., 2004; Strazdina, 2007; Strazdina, 2008).

During 20 years (1990-2010) at the State Stende CBI, 1765 spring wheat crossing combinations were conducted and 84 200 seeds were obtained. The average fertility was $32.8 \%$. 
WINTER WHEAT VARIETIES CREATED FROM 1990 TO 2010 IN LATVIA

\begin{tabular}{|c|c|c|c|}
\hline Variety & Origin & Originators & Year of registration \\
\hline 'Elva' & 'Zarya'/'Kato' & $\begin{array}{l}\text { V. Strazdina, M. Ceraukste } \\
\text { M. Krotovs } \\
\text { M. Roze }\end{array}$ & 1996 \\
\hline 'Hugo’ & 'Donskaya polukarlikovaya'/ 'Mironovskaya 808' & $\begin{array}{l}\text { V. Strazdina, M. Ceraukste } \\
\text { M. Krotovs } \\
\text { I. Priekule }\end{array}$ & 1997 \\
\hline 'Sakta' & 'Mironovskaya 1451'/‘Grana' & $\begin{array}{l}\text { V. Strazdina, M. Ceraukste } \\
\text { R. Kude } \\
\text { M. Krotovs } \\
\text { M. Roze }\end{array}$ & 1994 \\
\hline 'Banga S' & 'Mironovskaya 808'/ 'Sojuz'// 'Grana/Mironovskaja 808' & $\begin{array}{l}\text { V. Strazdina, M. Ceraukste } \\
\text { M. Krotovs } \\
\text { I. Koptiks }\end{array}$ & 2002 \\
\hline 'Moda' (Otto) & 'Donskaya polukarlikovaya'/ 'Abe' & $\begin{array}{l}\text { I. Belicka } \\
\text { A. Liepa } \\
\text { V. Strazdina }\end{array}$ & 2001 \\
\hline 'Fredis' & 'Donskaja polukarlikovaya'/ 'Abe'// 'Lowrin 24' & $\begin{array}{l}\text { V. Strazdina, M. Ceraukste } \\
\text { S. Maliecka }\end{array}$ & $\begin{array}{l}2007 \text { (in Latvia) } \\
2011 \text { (in Estonia) }\end{array}$ \\
\hline 'Talsis' & 'Veselanka'/‘Nadzeja' & V. Strazdiņa, M. Ceraukste & Under testing from 2007 \\
\hline 'Edvins' & WHQ91058/OR908173 & $\begin{array}{l}\text { V. Strazdina, M. Ceraukste } \\
\text { W.E. Kronstad }\end{array}$ & Under testing from 2008 \\
\hline
\end{tabular}

CHARACTERISATION OF WINTER WHEAT VARIETIES, STENDE 2007-2010

\begin{tabular}{|c|c|c|c|c|c|c|}
\hline Variety & $\begin{array}{l}\text { Yield, } \\
\text { t ha }^{-1}\end{array}$ & Yield, \% & $\begin{array}{c}\text { Winter hardiness, } \\
1-9 \text { point }\end{array}$ & $\begin{array}{l}\text { Lodging resistance, } \\
1-9 \text { point }\end{array}$ & Heading date & Plant height, $\mathrm{cm}$ \\
\hline 'Olivin', standard & 7.85 & 100.0 & $5-7$ & 7 & 19.06 & 90 \\
\hline 'Fredis' & 7.34 & 93.50 & $7-9$ & 7 & 04.06 & 77 \\
\hline 'Talsis' & 8.12 & 103.43 & 7 & $5-7$ & 11.06 & 92 \\
\hline 'Edvins' & 8.01 & 102.03 & $7-9$ & $5-7$ & 06.06 & 97 \\
\hline
\end{tabular}

From 2001 to 2007 , the new spring wheat variety 'Uffo' ('Sigma'/'Eta') was created at the State Stende CBI. The authors of this variety were V. Strazdina, M. Ceraukste, M. Bleidere, G. Lanka, Z. Opmane, and S. Malecka. The variety 'Uffo' is a mid-early variety, with yield potential 6-8 $\mathrm{t} \mathrm{ha}^{-1}$ and moderate lodging resistance (3-5). Grain quality is suitable for food and feed. Variety 'Uffo' is included in Latvian Plant Catalogue from 2008 and in the Estonian Plant Catalogue from 2009 (Tables 10 and 11).

Spring wheat variety 'Robijs' (preliminary name 'DH-3'), obtained from crossing combinations (Dragon/Anninia// Fasan) by anther culture, was developed at the State Stende Cereals Breeding Institute in collaboration with the Institute of Biology University of Latvia from 2001 to 2007. Authors of the variety are V. Strazdina, M. Ceraukste, D. Grauda, and I. Rashal. The variety is a middle-early (three days later compared with the standard 'Vinjett') with high yield potential $\left(6-8\right.$ tha $\left.^{-1}\right)$, plant height $93-98 \mathrm{~cm}$, and moderate re-
Table 9 GRAIN QUALITY OF WINTER WHEAT VARIETIES, STENDE 2007-2010

\begin{tabular}{l|c|c|c|c|c}
\hline \multicolumn{1}{c|}{ Variety } & $\begin{array}{c}\text { Protein } \\
\text { content, } \\
\mathrm{g} \mathrm{kg}^{-1}\end{array}$ & $\begin{array}{c}\text { Gluten } \\
\text { content, } \\
\mathrm{g} \mathrm{kg}^{-1}\end{array}$ & $\begin{array}{c}\text { Zeleny } \\
\text { index, } \\
\mathrm{m} \mathrm{L}\end{array}$ & $\begin{array}{c}\text { Falling } \\
\text { number, } \\
\mathrm{s}\end{array}$ & $\begin{array}{c}\text { Starch } \\
\text { content, } \\
\mathrm{g} \mathrm{kg}^{-1}\end{array}$ \\
\hline 'Olivin', standard & 126 & 245 & 46.1 & 347 & 666 \\
'Fredis' & 138 & 286 & 58.3 & 280 & 623 \\
'Talsis' & 129 & 253 & 52.4 & 385 & 632 \\
'Edvins' & 131 & 264 & 60.1 & 305 & 642
\end{tabular}

sistance to lodging (7 points) (Table 10). It also has moderate resistance to Blumeria graminis (DC.) E.O. Speer f. sp. tritici Em. Marchal, Puccinia triticina Eriks\&Henn, and it is susceptible to Drechslera tritici- repentis (Died) Shoem (5-7 points). The grain quality is suitable for food (Table 11). Variety 'Robijs' is included in the Latvian Plant Catalogue from 2011. 
CHARACTERISATION OF SPRING WHEAT VARIETIES, STENDE 2007-2010

\begin{tabular}{l|c|c|c|c|c|c}
\hline \multicolumn{1}{c|}{ Variety } & $\begin{array}{c}\text { Yield, } \\
\text { t ha }^{-1}\end{array}$ & $\begin{array}{c}\text { Yield, } \\
\%\end{array}$ & $\begin{array}{r}\text { Lodging } \\
\text { resistance, } \\
1-9 \text { point }\end{array}$ & $\begin{array}{c}\text { Growing } \\
\text { period, } \\
\text { days }\end{array}$ & $\begin{array}{c}\text { Plant } \\
\text { height, } \\
\text { cm }\end{array}$ & $\begin{array}{c}\text { TGW, } \\
\mathrm{g}\end{array}$ \\
\hline 'Vinjett', standard & 6.60 & 100.00 & 7 & 96 & 98 & 39.0 \\
'Uffo' & 6.96 & 105.45 & $5-7$ & 98 & 94 & 40.1 \\
'Robijs' & 7.54 & 114.24 & 7 & 99 & 95 & 43.2
\end{tabular}

Table 11

GRAIN QUALITY OF SPRING WHEAT VARIETIES, STENDE 2007-2010

\begin{tabular}{l|c|c|c|c|c}
\hline Variety & $\begin{array}{c}\text { Protein } \\
\text { content, } \\
\mathrm{g} \mathrm{kg}^{-1}\end{array}$ & $\begin{array}{c}\text { Gluten } \\
\text { content, } \\
\mathrm{g} \mathrm{kg}^{-1}\end{array}$ & $\begin{array}{c}\text { Zeleny } \\
\text { index, } \\
\mathrm{m} \mathrm{L}\end{array}$ & $\begin{array}{c}\text { Falling } \\
\text { number, } \\
\mathrm{s}\end{array}$ & $\begin{array}{c}\text { Volume } \\
\text { weight, } \\
\mathrm{g} \mathrm{L}^{-1}\end{array}$ \\
\hline 'Vinjett', standard & 128 & 280 & 47 & 250 & 778 \\
'Uffo' & 126 & 250 & 43 & 345 & 782 \\
'Robijs' & 128 & 260 & 44 & 343 & 798
\end{tabular}

\section{REFERENCES}

Anonīms (1927-1940). Latviešu Konversācijas vārdnīca. Rīga: A. Gulbja apgāds. 19.-43. 1pp.

Anonīms (1992). Laukaugu selekcija Latvijā. Holms, I. (sast.). Rīga: Avots. 189 lpp.

Belicka, I. (2002). Ziemas kviešu škirnes 'Moda' (Otto) izveide un raksturojums. Agronomijas Vēstis (Jelgava), Nr. 4, 156-162.

Garbars, J. (1939). Ziemas un vasaras kviešu selekcijas un izmēgeinājumu darbu rezultāti, Stendes selekcijas stacijā 1928.-1937. g. 121 lpp.

Grauda, D., Keisa, A., Rashal, I. (2005). Obtaining of doubled haploid lines for Latvian barley and wheat breeding programs by anther culture method. In: Plant Breeding and Seed Science, IX (pp. 209-216). Annamaa, K. (Ed.). Jõgeva: Jõgeva Plant Breeding Institute.

Grauda, D., Lepse, N., Strazdiņa, V., Kokina, I., Lapiņa, L., Miķelsone, A., Lublinskis, L., Rashal, I. (2010). Obtaining of doubled haploid lines by anther culture method for the Latvian wheat breeding. Agron. Res., 8, $545-553$.

Grauda, D., Strazdina, V., Kokina, I., Lapina, L., Mikelsone, A., Rashal, I. (2009). Extension of spring wheat breeding using doubled haploids technology. Acta Biol. Univ. Daugavpiliensis, 9, 34-38.

Lielmanis, J., Bērzin̄š, E., Garbars, J. (1931). Selekcijas un izmēéinājumu darbi. Rīga. 287 lpp.

Rashal, I. (2001). The PGR network in Latvia. Biologija (Lithuania), 4, 20-22.

Rashal, I. (2002). Latvian Gene Bank of Cultivated Plants: the first steps. In: Broad Variation and Precise Characterization - Limitation for the Fu-
Workshop, May 16-20 2001, Poznań, Poland (pp. 81-83). Świécicki, W., Naganowska, B., Wolko, B. (eds.). Poznań.

Rashal, I.,Weibull, J. (1997). Latvian plant genetic resources: Co-operation with the Nordic Gene Bank. Proc. Latvian Acad. Sci., Section B, 51(1/2), $84-85$

Roze, M, Strazdina, V. (1993). Winter wheat breeding for baking quality at the State Stende Agriculture Research Station. Proceedings of the 25th Nordic Cereal Congress. The Nordic Cereal Industry in an Integrating Europe (pp.162-166). Helsinki.

Strazdina, V. (1996). Results and prospects of winter wheat breeding in Latvia. $5^{\text {th }}$ International Wheat Conference, 10-14 June (p. 84). Ankara.

Strazdiṇa, V. (1999). Ziemas kviešu izejmateriāla izpēte un tā pielietojums škirṇu veidošanā. Zinātniskais darbs maǵistra grāda ieguvei. Jelgava. 113 lpp.

Strazdina, V. (2007). Wheat genetic resources and utilization in breeding programmes in Latvia. Proceedings of the International Scientific Conference Plant Breeding: Scietific and practical aspects to mark the 85 the anniversary of the National Plant Breeding in Lithuania, 3-5 July (p. 24). Dotnuva.

Strazdina, V. (2008). Evaluation of main traits and their relationships of spring wheat. Latv. J. Agron. (Agronomijas vēstis (Jelgava), 11, 154-158.

Strazdina, V., Bleidere, M. (2004). Cereal varieties for organic farming in Latvia. Proceedings of the First World Conference on Organic Seed, July 5-7, Rome (pp. 186-187). Rome.

Strazdina, V, Bleidere, M., Zute, S. (2004). The first results of estimating cereal varieties for organic farming in Stende. International Conference of Baltic Cereal and Pea Breeders "Plant Breeding for Sustainable Agriculture”, 28-30 June (pp. 40-42). State Stende Plant Breeding Station, Latvia.

Strazdina, V., Briedis, J. (2004). Distinctness, Uniformity, Stability test of cereal varieties at State Stende Plant Breeding Station. International Conference of Baltic Cereal and Pea Breeders, "Plant Breeding for Sustainable agriculture”, 28-30 June (p. 43). State Stende Plant Breeding Station, Latvia.

Strazdina, V., Krotovs, M. (1996). Ziemas kviešu šḳirnes 'Banga' raksturojums un tās audzēšanas tehnologijas. LLMZA, LLU lauksaimniecības fakultātes zinātniskās konferences raksti. Jelgava. 113. 1pp.

Strazdiṇa, V., Lanka, G., Priekule, I. (1995). Kviešu selekcijas izejmateriāla izpēte Valsts Stendes selekcijas un izmēǵinājumu stacijā. LLMZA, LLU lauksaimniecības fakultātes Zinātniski praktiskās konferences materiāli (30. 1pp). Jelgava.

Страздиня В.А. (1987). Итоги селекции озимой пшеницы на Стендской опытно-селекционной станции с 1981 по 1985 г. В кн.: Генетика и селекция в Латвийской ССР (с. 56-59). И.Д. Рашаль (отв. ред.). Рига: Зинатне.

Страздиня В.А., Розе М.В. (1992). Селекция пшеницы в Латвии. Вестник сельскохозяйственной науки, 112, 83-84.

Чмелёва 3.В., Страздиня В.А, Удачин Р.А., Ермолаева Л.Н., Лавринова В.И. (1989). Каталог мировой коллекции ВИР. В кн.: Kормовые пиенииь в условиях Латвийской ССР, Вып. 484 (с. 48). Ленинград.

Received 15 February 2012

\section{KVIEŠU AUDZĒŠANAS VĒSTURE LATVIJĀ}

Latvijas ziemas un vasaras kviešu (Triticum aestivum L.) genofonds ir veidojies vairāk nekā 90 gadu garumā no labākajām vietējā materiāla formām, augsnes un klimatiskajiem apstāklịem piemērotākajām ārzemju šḳirnēm, hibridizācijas un izlases rezultātā veidotajām līnijām. Tas ir stabils pamats zinātniskajiem pētījumiem augu bioloǵijā un ǵenētikā, kā arī turpmākajam selekcijas darbam — radīt un ieviest ražošanā augstražīgas kviešu škirnes, kas ir izturīgas pret veldrēšanos, slimībām un kaitēkḷu bojājumiem, ar graudu kvalitāti atbilstošu pārstrādātāju prasībām, piemērotas audzēšanai Baltijas reǵionā. Selekcijas sākuma posmā Latvijā veidotās kviešu škirnes pārsvarā bija populācijas. Škirṇu reǵistrācijas noteikumi, Latvijai pievienojoties ES un starptautiskajai šķirṇu aizsardzības organizācijai UPOV, mainījās un noteica, ka tikai atškirīgas, viendabīgas un stabilas līnijas ar augstvērtīgām saimnieciskām īpašībām var tikt reǵistrētas Augu škiinnu katalogā. Veidojot škirnes ar klasiskajām selekcijas metodēm, darbam nepieciešami 12-15 gadi, bet, izmantojot biotehnoloǵijas metodes (dubultie haploīdi), selekcijas laiks saīsinās. Latvijā Stendē un Priekuḷos (1922-2011) kviešu selekcijas darba rezultātā ir izveidotas 16 ziemas kviešu un 11 vasaras kviešu škirnes. 